\title{
The Stimulus-Secretion Coupling of Amino Acid-Induced Insulin Release
}

\author{
Biosynthetic and Secretory Responses of Rat Pancreatic Islet to L-Leucine and L-Glutamine \\ A. Sener, G. Somers, G. Devis and W. J. Malaisse \\ Laboratory of Experimental Medicine, Brussels University School of Medicine, Brussels, Belgium
}

Summary. L-glutamine dramatically augments insulin release evoked by L-leucine. The dynamics, specificity and environmental modifications of the insulin secretory response to the combination of L-glutamine and L-leucine were investigated. Lglutamine alone failed to stimulate proinsulin biosynthesis or insulin release in rat pancreatic islets, but augmented synthesis and secretion evoked by Lleucine. In relation to the secretory response, Lglutamine could be replaced by L-asparagine but not L-glutamate; L-leucine could be replaced by L-norvaline or $\mathrm{L}$-isoleucine but not by $\mathrm{L}$-valine, $\mathrm{L}$-norleucine, glycine, L-serine, L-lysine, L-phenylalanine or L-arginine. The secretory response to L-leucine was rapid and biphasic, whereas the enhancing action of L-glutamine upon insulin release was progressive. The release of insulin evoked by the combination of L-leucine and L-glutamine was inhibited by antimycin A, menadione, ammonium ions, verapamil, adrenaline, and by the absence of extracellular $\mathrm{Ca}^{2+}$. It was increased at high carbon dioxide tension, and by glucose, theophylline and cytochalasin B. It is concluded that the enhancing action of L-glutamine upon insulin release evoked by certain amino acids represents a phenomenon dependent on the integrity of oxidative metabolism and involving essentially the same sequence of metabolic, ionic and motile events as that characterizing the process of glucose-induced insulin release.

Key words: Insulin release, proinsulin biosynthesis, pancreatic islets, amino acids, L-leucine, Lisoleucine, L-norvaline, L-valine, L-norleucine, glycine, L-serine, L-lysine, L-phenylalanine, L-arginine, L-glutamine, L-asparagine, L-glutamate.
Amino acids stimulate insulin release [1]. The clinical relevance of such a phenomenon is best illustrated by the syndrome of leucine-induced hypoglycaemia, a condition which led to the discovery of the stimulant action of L-leucine and other amino acids upon insulin release [1].

It was recently reported that L-glutamine, which represents a major fuel for pancreatic islet cells but which fails to stimulate insulin release in the presence or absence of glucose [2], dramatically enhanced insulin secretion evoked by either L-leucine or its non-metabolised analogue $b(-) 2$-aminobicyclo$[2,2,1]$ heptane-2-carboxylic acid [3]. This finding is of considerable significance in elucidating the biochemical determinant(s) of amino acid-induced insulin release.

The aim of the present study was to characterize the dynamics, specificity and environmental modification of the secretory response to the combination of L-glutamine and L-leucine, and to investigate the effect of such a combination upon proinsulin biosynthesis in isolated rat pancreatic islets. In order to facilitate the interpretation of results, most experiments were performed in the absence of $\mathrm{D}$-glucose, using concentrations of amino acids far above their physiological values.

\section{Methods}

The methods used to measure insulin release [4] and proinsulin biosynthesis [5] in isolated islets and insulin release in isolated perfused pancreases [6] removed from fed albino rats are described in detail elsewhere. Briefly, groups of eight islets each were incubated for $90 \mathrm{~min}$ in $1.0 \mathrm{ml}$ of a medium containing $\mathrm{Na}^{+}$ $139, \mathrm{~K}^{+} 5, \mathrm{Ca}^{2+} 1, \mathrm{Mg}^{2+} 1, \mathrm{Cl}^{-} 124$ and $\mathrm{HCO}_{5}{ }^{-} 24 \mathrm{mmol} / \mathrm{l}$ and bovine albumin $(5 \mathrm{mg} / \mathrm{ml})$. Except for the presence of dextran [7] in the perfusate, the media used for incubating islets or perfusing pancreases were of identical composition. In order to increase the $\mathrm{CO}_{2}$ tension whilst maintaining extracellular $\mathrm{pH}$ unchanged (7.4), 

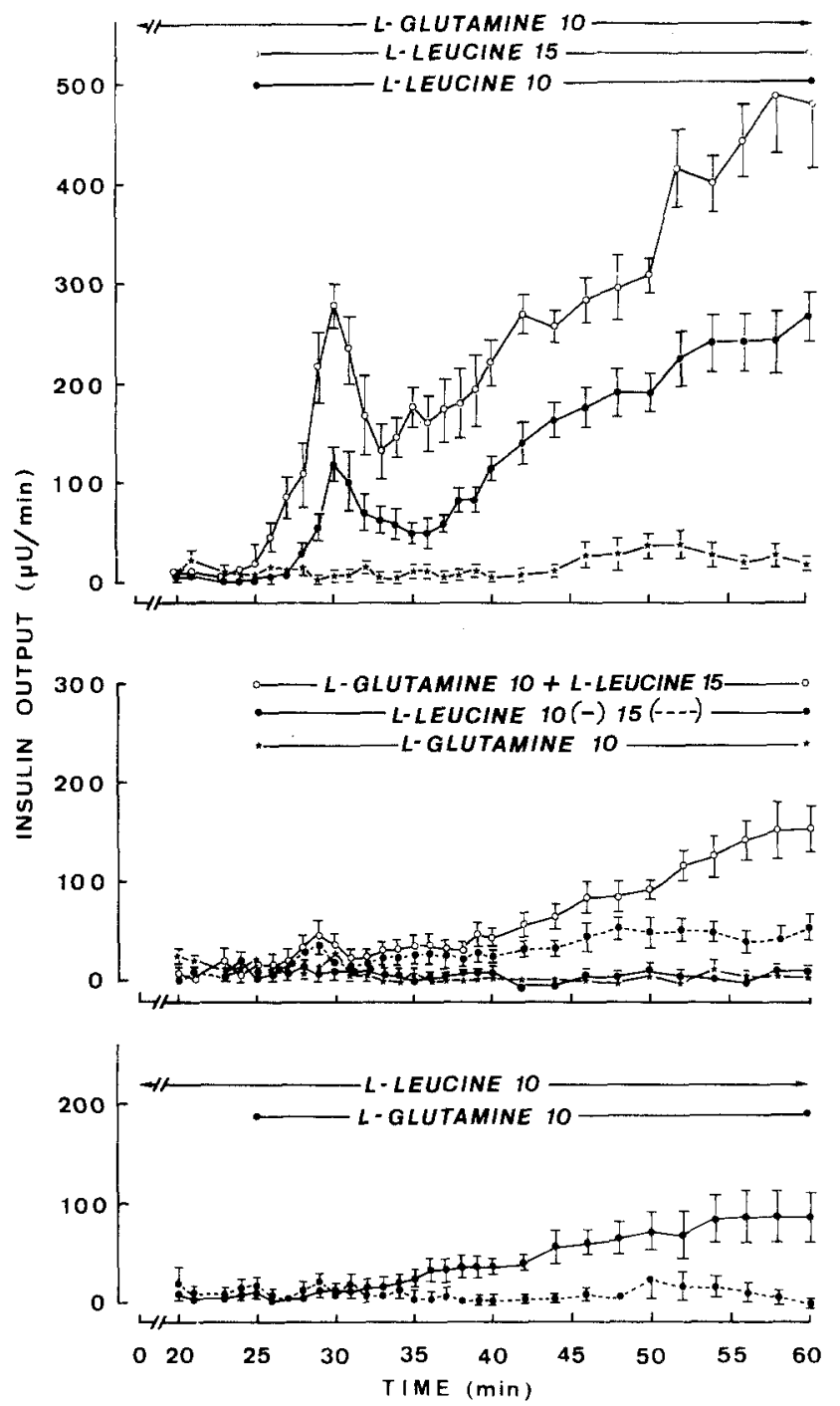

Fig. 1. Effect of L-leucine and L-glutamine upon insulin release by the isolated perfused rat pancreas. Upper panel: effect of $\mathrm{L}$ leucine (10 mmol/1: $\longrightarrow ; n=5 ; 15 \mathrm{mmol} / \mathrm{l}: 0 \_0 ; n=6$ ) administered from min 25 onwards upon insulin release in the presence of $\mathbf{L}$-glutamine $(10 \mathrm{mmol} / \mathrm{l})$ administered throughout the perfusion period; control data obtained in the sole presence of $\mathrm{L}$ glutamine ( $\star-\star ; n=3$ ). Middle panel: effect of L-glutamine alone (10 mmol/1: $\star$ —— ), L-Leucine alone $\left(10 \mathrm{mmol} / \mathrm{l}:-\_\right.$ $n=3 ; 15 \mathrm{mmol} / \mathrm{l}:-\mathbf{C}^{-} ; n=4$ and the combination of $\mathrm{L}$ glutamine $(10 \mathrm{mmol} / \mathrm{l})$ and $\mathrm{L}$-leucine $(15 \mathrm{mmol} / \mathrm{l}: 0-0 ; n=4)$, the amino acids being always administered from min 25 onwards. Lower panel: effect of L-glutamine ( $10 \mathrm{mmol} / \mathrm{l}:-0 ; n=6)$ administered from min 25 onwards in the presence of L-leucine $(10 \mathrm{mmol} / \mathrm{l})$ administered throughout the perifusion period; control data obtained in the sole presence of L-leucine $(10 \mathrm{mmol} / 1)$ are shown $(\bullet-n=3)$

the usual gas phase $\left(\mathrm{O}_{2} / \mathrm{CO}_{2}: 95 / 5 \%, \mathrm{v} / \mathrm{v}\right)$ was replaced by a mixture of $70 \% \mathrm{O}_{2}$ and $30 \% \mathrm{CO}_{2}$, and the $\mathrm{HCO}_{3}{ }^{-}$concentration of the medium increased from 24 to $102 \mathrm{mmol} / 1$ at the expense of the $\mathrm{Cl}^{-}$concentration [8].

L-leucine, L-norvaline, L-isoleucine, L-valine, L-norleucine, glycine, L-serine, L-phenylalanine, L-arginine and L-glutamate were obtained from Merck, Darmstadt, FRG; L-glutamine, antimycin A and menadione from Sigma Chemicals, St. Louis, Missouri; theophylline from Schwartz/Mann, Organeburg, New York; verapamil from Knoll A. G., Ludwigshafen, FRG; adrenaline from Federa, Brussels, Belgium; the trifluoromethylphenothiazine derivative of domperidone from Janssen Pharmaceutica, Beerse, Belgium; cytochalasin $\mathbf{B}$ and $\mathbf{L}$-asparagine from Aldrich, Milwaukee, Wisconsin, L-Lysine from Koch-Light Laboratories, Colnbrook, Bucks, UK; and L- $\left[2,4,6-{ }^{3} \mathrm{H}\right]$ phenylaline from The Radiochemical Centre, Amersham, UK.

All results are expressed as mean \pm SEM together with the number of individual determinations (n). Except for the perfusion experiments, the comparison of control and experimental values is restricted to data obtained within the same experiment(s), using Student's t-test for group comparison. In each experiment, all islets were derived from the same preparation and, usually, an equal number of individual determinations were performed under control and experimental conditions.

\section{Results}

\section{Dynamics of the Secretory Response to L-Leucine and L-Glutamine}

The dynamics of the secretory response to L-leucine and L-glutamine were investigated in the isolated perfused pancreas (Fig. 1). When L-glutamine $(10 \mathrm{mmol} / \mathrm{l})$ was administered alone either throughout the $60 \mathrm{~min}$ or over the last $35 \mathrm{~min}$ of perfusion, the rate of insulin release remained close to basal value. Likewise, when L-leucine $(10 \mathrm{mmol} / \mathrm{l})$ was administered alone throughout the $60 \mathrm{~min}$ or over the last 35 min of perfusion, the rate of secretion was only slightly and occasionally higher than basal value. The concentration of L-leucine had to be raised to $15 \mathrm{mmol} / \mathrm{l}$ to evoke an easily discernible biphasic secretory response.

The secretory response to L-leucine was considerably augmented in the presence of L-glutamine. The enhancing action of L-glutamine was most evident when the latter amino acid was circulated for $25 \mathrm{~min}$ before stimulation with L-leucine (Fig. 1, upper panel). Under these conditions, both the initial and late secretory responses to L-leucine were considerably enhanced. The rate of secretion was 7-20 times higher than in the absence of L-glutamine (Table 1).

The enhancing action of L-glutamine was much less marked when both amino acids were introduced together at min 25 of the perfusion. Indeed, in this case, the secretory response to L-leucine was increased mostly during the late phase of stimulation, and the integrated output of insulin was only double that in the absence of L-glutamine (Table 1).

When the pancreases were first exposed to Lleucine before introduction of L-glutamine, an enhancing action of the latter amino acid was again 
Table 1. Insulin output evoked by L-glutamine and L-leucine in the isolated perfused rat pancreas

\begin{tabular}{lll}
\hline $\begin{array}{l}\text { L-glutamine } \\
\text { (mmol/1) }\end{array}$ & $\begin{array}{l}\text { L-leucine } \\
(\mathrm{mmol} / \mathrm{l})\end{array}$ & Insulin output $^{\mathrm{a}}$ \\
\hline $10(25-60)^{\mathrm{b}}$ & - & $0.18 \pm 0.03(3)$ \\
- & $10(25-60)$ & $0.24 \pm 0.13(3)$ \\
- & $10(0-60)$ & $0.32 \pm 0.09(3)$ \\
$10(25-60)$ & $10(0-60)$ & $1.68 \pm 0.43(6)$ \\
$10(0-60)$ & $10(25-60)$ & $5.07 \pm 0.50(5)$ \\
- & $15(25-60)$ & $1.32 \pm 0.07(4)$ \\
$10(25-60)$ & $15(25-60)$ & $2.54 \pm 0.32(4)$ \\
$10(0-60)$ & $15(25-60)$ & $9.63 \pm 0.68(6)$ \\
\hline
\end{tabular}

a Results are expressed as $\mathrm{mU} /$ pancreas and represent the integrated output of insulin between min 25 and $\min 60$ of perfusion. For purpose of comparison, the integrated output evoked by $\mathrm{D}$ glucose $16.7 \mathrm{mmol} / \mathrm{l}$ (administered from $\min 25-60$ averaged $13.60 \pm 2.97 \mathrm{mU} /$ pancreas $(n=5)$. Mean values \pm SEM are shown together with the number of individual determinations

$\mathrm{b}$ The period ( $\mathrm{min}$ ) during which each amino acid was administered is shown in parentheses

evident, but the secretory rate increased in a progressive manner, in contrast to the biphasic pattern usually evoked by nutrient secretagogues.

\section{Specificity of the Secretory Response to L-Leucine and L-Glutamine}

Further experiments were performed with isolated rat pancreatic islets. We have previously shown that the secretory response to leucine and glutamine is stereospecific for the $\mathrm{L}$-form of these amino acids [3].

L-glutamine could not be replaced by L-glutamate in its capacity to potentiate L-leucine-induced insulin release (Table 2, experiment 4). L-glutamate did not prevent L-glutamine from augmenting $\mathrm{L}$ leucine-stimulated secretion. L-asparagine, like Lglutamine, was able to cause a dose-related potentiation of L-leucine-induced insulin release (Table 2, experiment 3 ). In this respect and on a molar basis, L-glutamine was more potent than L-asparagine. Lasparagine, like L-glutamine [2], did not affect insulin release in the absence of another nutrient (Table 2 , experiment 1 ) and failed to enhance significantly glucose-induced insulin release (Table 2, experiment 2). L-asparagine did not prevent L-glutamine from augmenting $\mathrm{L}$-leucine-induced insulin release (Table 2 , experiment 3). Several amino acids other than Lglutamine and $\mathrm{L}$-asparagine were able to augment $\mathrm{L}$ leucine-induced insulin release (see below). In contrast to L-glutamine and L-asparagine, all these other amino acids also significantly enhanced D-glucosestimulated insulin secretion. Moreover, none of these other amino acids enhanced L-leucine-induced insu- lin release to the same extent as L-glutamine or even L-asparagine.

The specificity towards L-leucine was explored by testing the capacity of L-glutamine to augment insulin release in the presence of each of ten different amino acids (Table 3). L-glutamine significantly enhanced insulin release in the presence of L-leucine, L-norvaline and L-isoleucine. The enhancing action of L-glutamine was most marked with L-leucine and least marked with L-isoleucine. L-glutamine failed to enhance significantly insulin release in the presence of L-valine, L-norleucine, glycine, L-serine, L-lysine, L-phenylalanine or L-arginine.

The magnitude of the glutamine-induced increment in insulin output was not closely related to the capacity of a given amino acid to stimulate secretion in the absence of any other exogenous nutrient. For instance, in the presence of $5 \mathrm{mmol} / 1 \mathrm{~L}$-leucine, $20 \mathrm{mmol} / 1 \mathrm{~L}$-norvaline and $20 \mathrm{mmol} / \mathrm{l} \mathrm{L}$-lysine, comparable values for insulin output were found in the absence of any other nutrient (i. e. $34.5 \pm 2.6,39.5$ \pm 2.8 and $44.7 \pm 5.0 \mu \mathrm{U} /$ islet per $90 \mathrm{~min}$, respectively), whereas the response to L-glutamine $(10 \mathrm{mmol} / \mathrm{l})$ was strikingly variable: the glutamineinduced increase in insulin output was more than double in the presence of $5 \mathrm{mmol} / \mathrm{l} \mathrm{L}$-leucine (data not shown) than $20 \mathrm{mmol} / 1 \mathrm{~L}$-norvaline, and no effect of L-glutamine could be detected in the presence of $20 \mathrm{mmol} / 1 \mathrm{~L}$-lysine.

With the exception of L-valine and L-arginine, all amino acids listed in Table 3 augmented significantly either L-leucine- or D-glucose-stimulated insulin release. L-valine failed to affect secretion whether in the presence of L-leucine or D-glucose. L-arginine dramatically enhanced secretion in the presence of D-glucose, but failed to do so and even occasionally inhibited release in the presence of L-leucine. There was no obvious link between the capacity of Lglutamine to augment secretion evoked by a given amino acid and the aptitude of that same amino acid to augment release in the presence of either Lleucine or D-glucose (Table 3).

\section{Environmental modification of the secretory response to L-Leucine and L-Glutamine}

The release of insulin evoked by the combination of L-leucine and L-glutamine $(10 \mathrm{mmol} / \mathrm{l}$ each $)$ was significantly lower than that induced by $\mathrm{D}$-glucose $16.7 \mathrm{mmol} / 1(p<0.001 ; \mathrm{df}=82)$. D-glucose caused a dose-related increase in the secretory response to the combination of L-leucine and L-glutamine (Fig. 2). Even at a $16.7 \mathrm{mmol} / \mathrm{l}$ concentration of glucose, the secretory rate was significantly higher in the presence of the two amino acids than in their absence 
Table 2. Effects of $D$-glucose and various amino acids upon insulin release

\begin{tabular}{|c|c|c|c|c|c|c|}
\hline $\begin{array}{l}\text { Experiment } \\
\text { no. }\end{array}$ & $\begin{array}{l}\text { D-glucose } \\
(\mathrm{mmol} / \mathrm{l})\end{array}$ & $\begin{array}{l}\text { L-leucine } \\
(\mathrm{mmol} / \mathrm{l})\end{array}$ & $\begin{array}{l}\text { L-glutamate } \\
(\mathrm{mmol} / \mathrm{l})\end{array}$ & $\begin{array}{l}\text { L-glutamine } \\
(\mathrm{mmol} / \mathrm{l})\end{array}$ & $\begin{array}{l}\text { L-asparagine } \\
(\mathrm{mmol} / \mathrm{l})\end{array}$ & $\begin{array}{l}\text { Insulin output }{ }^{\mathbf{a}} \\
(\mu \mathrm{U} / \text { islet per } 90 \mathrm{~min})\end{array}$ \\
\hline \multirow[t]{4}{*}{1} & - & - & - & - & - & $11.3 \pm 1.2(62)$ \\
\hline & - & - & - & - & 10.0 & $15.2 \pm 3.7(9)$ \\
\hline & - & - & - & 10.0 & - & $11.3 \pm 0.9(136)$ \\
\hline & - & - & - & 10.0 & 10.0 & $12.7 \pm 4.9(10)$ \\
\hline \multirow[t]{4}{*}{2} & 8.3 & - & - & - & - & $81.0 \pm 7.1(27)$ \\
\hline & 8.3 & - & - & - & 1.0 & $76.5 \pm 7.5(9)$ \\
\hline & 8.3 & - & - & - & 3.0 & $79.1 \pm 7.8(9)$ \\
\hline & 8.3 & - & - & - & 10.0 & $109.3 \pm 10.9(28)$ \\
\hline \multirow[t]{7}{*}{3} & - & 10.0 & - & - & - & $49.5 \pm 3.6(36)$ \\
\hline & - & 10.0 & - & - & 1.0 & $54.4 \pm 5.4(9)$ \\
\hline & - & 10.0 & - & - & 3.0 & $76.8 \pm 7.3(18)$ \\
\hline & - & 10.0 & - & - & 10.0 & $111.8 \pm 8.2(44)$ \\
\hline & - & 10.0 & - & 3.0 & - & $193.7 \pm 6.2(9)$ \\
\hline & - & 10.0 & - & 3.0 & 3.0 & $194.8 \pm 3.2(9)$ \\
\hline & - & 10.0 & - & 10.0 & - & $247.1 \pm 8.8(17)$ \\
\hline \multirow[t]{4}{*}{4} & - & 20.0 & - & - & - & $76.2 \pm 5.1(17)$ \\
\hline & - & 20.0 & - & 10.0 & - & $184.1 \pm 5.8(17)$ \\
\hline & - & 20.0 & 10.0 & - & - & $84.8 \pm 9.8(10)$ \\
\hline & - & 20.0 & 5.0 & 5.0 & - & $173.9 \pm 5.1(10)$ \\
\hline
\end{tabular}

${ }^{a}$ Mean values \pm SEM are shown with the number of individual determinations in parentheses

Table 3. Effect of amino acids upon insulin release in the absence of any other nutrient and in the presence of either L-glutamine, L-leucine or $\mathrm{D}$-glucose

\begin{tabular}{llccc}
\hline Nutrient (mmol/l) & Nil & $\begin{array}{l}\text { L-glutamine } \\
(10 \mathrm{mmol} / \mathrm{l})\end{array}$ & $\begin{array}{l}\text { L-leucine } \\
(10 \mathrm{mmol} / \mathrm{l})\end{array}$ & $\begin{array}{l}\text { D-glucose } \\
(8.3 \mathrm{mmol} / \mathrm{l})\end{array}$ \\
\hline Nil & $15.4 \pm 1.8(56)$ & $13.6 \pm 2.2(40)$ & $54.0 \pm 2.5(74)$ & $97.2 \pm 4.1(132)$ \\
L-leucine (10) & $54.0 \pm 2.5(74)^{\mathrm{b}}$ & $196.1 \pm 13.1(28)^{\mathrm{b}}$ & $84.7 \pm 4.1(20)^{\mathrm{a} b}$ & $199.7 \pm 13.3(27)^{\mathrm{b}}$ \\
L-norvaline (20) & $39.5 \pm 2.8(39)^{\mathrm{b}}$ & $93.1 \pm 8.1(19)^{\mathrm{b}}$ & $93.7 \pm 6.0(10)^{\mathrm{b}}$ & $162.3 \pm 4.4(20)^{\mathrm{b}}$ \\
L-isoleucine (20) & $15.7 \pm 1.4(18)$ & $50.2 \pm 5.5(28)^{\mathrm{b}}$ & $86.7 \pm 4.9(20)^{\mathrm{b}}$ & $142.6 \pm 6.0(20)^{\mathrm{b}}$ \\
L-valine (20) & $14.8 \pm 2.1(20)$ & $21.8 \pm 3.9(20)$ & $52.6 \pm 5.7(10)$ & $101.0 \pm 5.9(20)$ \\
L-norleucine (20) & $12.7 \pm 1.6(9)$ & $14.6 \pm 2.2(17)$ & $88.1 \pm 6.9(10)^{\mathrm{b}}$ & $124.5 \pm 11.1(10)^{\mathrm{d}}$ \\
Glycine (10) & $18.0 \pm 2.7(19)$ & $25.1 \pm 2.2(9)$ & $99.4 \pm 1.8(9)^{\mathrm{b}}$ & $125.5 \pm 6.0(18)^{\mathrm{b}}$ \\
L-serine (10) & $20.2 \pm 2.5(10)$ & $19.7 \pm 2.1(10)$ & $99.7 \pm 4.7(9)^{\mathrm{b}}$ & $118.8 \pm 4.6(19)^{\mathrm{c}}$ \\
L-lysine (20) & $40.8 \pm 4.0(40)^{\mathrm{b}}$ & $40.3 \pm 7.9(10)$ & $77.6 \pm 6.0(9)^{\mathrm{c}}$ & $151.0 \pm 9.9(18)^{\mathrm{b}}$ \\
L-phenylalanine (10) & $20.1 \pm 3.4(10)$ & $23.0 \pm 2.4(10)$ & $86.3 \pm 5.8(9)^{\mathrm{b}}$ & $140.9 \pm 7.0(9)^{\mathrm{b}}$ \\
L-arginine (10) & $21.6 \pm 2.4(19)$ & $21.9 \pm 3.0(10)$ & $42.9 \pm 3.0(29)$ & $214.5 \pm 5.5(9)^{\mathrm{b}}$ \\
\hline
\end{tabular}

a The result shown at the intersection of L-leucine $10 \mathrm{mmol} / \mathrm{l}$ (third column) and L-leucine $10 \mathrm{mmol} / \mathrm{l}$ (second line) corresponds to the effect of L-leucine $20 \mathrm{mmol} / 1$

Levels of statistical significance ( ${ }^{\mathrm{b}}: p<0.001{ }^{\mathrm{c}}{ }^{\mathrm{c}}: p<0.005 ;{ }^{\mathrm{d}}: p<0.05$ ) refer either to the capacity of the amino acid to augment insulin output relative to the control value shown on the first line (column 1,3 and 4) or to the capacity of L-glutamine $10 \mathrm{mmol} / 1$ to augment amino acid-induced insulin release (column 2). Insulin release is expressed as $\mu$ U/islet per 90 min. Mean values $\pm S E M$ are shown with the number of individual determinations in parentheses

$(p<0.001 ; \mathrm{df}=64)$. We have characterized previously the effect of L-glutamine [2] and L-leucine [9] upon insulin release at increasing concentrations of D-glucose. When tested within the same experiments, the release of insulin evoked by L-leucine $10 \mathrm{mmol} / 1$ was virtually identical in the presence of D-glucose $8.3 \mathrm{mmol} / 1$ or L-glutamine $10 \mathrm{mmol} / 1$, the latter secretory rate averaging $98.2 \pm 1.1 \%(n=27)$ of the former $(100.0 \pm 1.1 \%, n=27)$. This contrasts with the vastly different secretory capacity of D-glucose and L-glutamine when tested in the absence of L-leucine (Table 3).

As shown in Table 4, the release of insulin evoked by L-leucine and L-glutamine was abolished 
by antimycin $A(10 \mu \mathrm{mol} / 1)$, the absence of extracellular $\mathrm{Ca}^{2+}$, and the presence of either verapamil $(10 \mu \mathrm{mol} / 1)$ or adrenaline $(5 \mu \mathrm{mol} / 1)$. It was inhibited in a dose-related fashion by increasing concentrations of menadione (Table 4) or decreasing concentrations of extracellular $\mathrm{Ca}^{2+}$ (Fig. 3), with an apparent " $\mathrm{Ki}$ " for menadione close to $6 \mu \mathrm{mol} / \mathrm{l}$ and an apparent " $\mathrm{Km}$ " for $\mathrm{Ca}^{2+}$ close to $0.2 \mathrm{mmol} / \mathrm{l}$. The secretory response to the combination of L-leucine and L-glutamine was decreased in the presence of a potential calmodulin-antagonist, the trifluoromethylphenothiazine derivative of domperidone $(1 \mu \mathrm{mol} / 1)$, slightly but significantly diminished in the presence of $\mathrm{NH}_{4}{ }^{+}(0.5 \mathrm{mmol} / \mathrm{l})$, slightly but significantly enhanced by an increase in $\mathrm{pCO}_{2}$, and dramatically potentiated by either theophylline $(1.4 \mathrm{mmol} / \mathrm{l})$ or cytochalasin B $(20 \mu \mathrm{mol} / 1)$. None of the agents listed in Table 4 affect basal insulin release.

Although the combination of L-leucine and Lglutamine (both $10 \mathrm{mmol} / \mathrm{l}$ ) displayed an insulinotropic capacity comparable to that of the combination of L-leucine $(10 \mathrm{mmol} / \mathrm{l})$ and $\mathrm{D}$-glucose $(8.3 \mathrm{mmol} / \mathrm{l})$, the influence of verapamil or of $\mathrm{Ca}^{2+}$ removal upon insulin release was not identical in the presence of these two combinations. The rate of insulin release was indeed significantly lower in the presence of verapamil or absence of extracellular $\mathrm{Ca}^{2+}$ when $\mathrm{L}$ leucine was used in combination with $\mathrm{L}$-glutamine as distinct from $\mathrm{D}$-glucose (Table 5).

\section{Biosynthetic Response to L-Leucine and L-Glutamine}

L-glutamine $(10 \mathrm{mmol} / \mathrm{l})$ failed to stimulate proinsulin biosynthesis as judged from the incorporation of $\mathrm{L}-\left[2,4,6-{ }^{3} \mathrm{H}\right]$ phenylalanine in immunoreactive insulin-like peptides (Table 6). L-leucine $(10 \mathrm{mmol} / \mathrm{l})$ stimulated the biosynthesis of both proinsulin and other islet peptides, with a preferential effect on proinsulin synthesis $(p<0.005)$. L-glutamine significantly augmented L-leucine-stimulated total protein and proinsulin biosynthesis, with again a preferential effect on the synthesis of the hormonal peptides $(p<0.01)$.

\section{Discussion}

The present findings confirm that L-glutamine markedly potentiates L-leucine-induced insulin release [3]. The concentrations of L-leucine and L-glutamine used in most of the present experiments largely exceed physiological values. However, at a physiological glucose concentration, the stimulant effect of L-leucine upon insulin release is virtually propor-

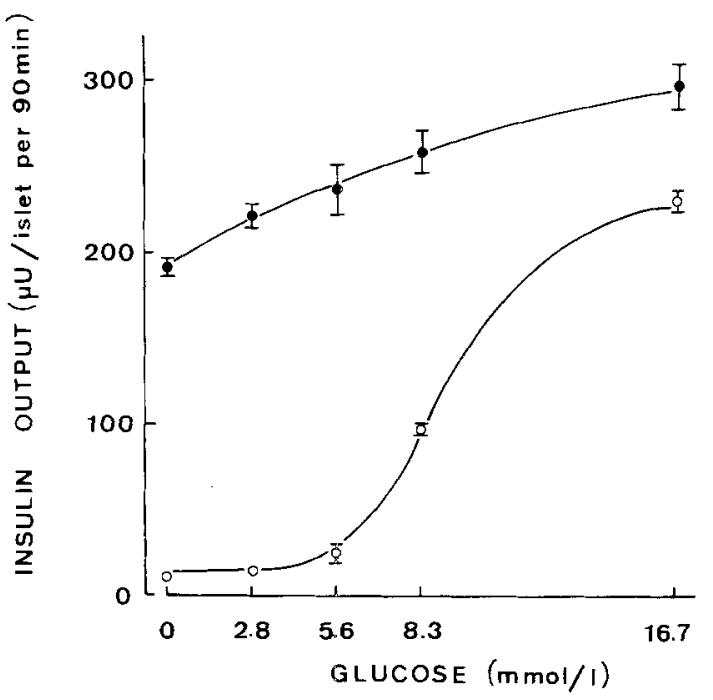

Fig. 2. Effect of increasing concentrations of D-glucose upon insulin release in the absence $(\mathrm{O}-\mathrm{O}$ ) and presence (-C) of the combination of L-glutamine and L-leucine $(10 \mathrm{mmol} / \mathrm{l}$ each $)$. Mean \pm SEM refer to 10-43 individual determinations

Table 4. Effect of several agents upon insulin release evoked by the combination of $\mathrm{L}$-glutamine and $\mathrm{L}$-leucine (both $10 \mathrm{mmol} / \mathrm{l}$ )

\begin{tabular}{|c|c|c|}
\hline Agent & Insulin output ${ }^{a}$ & $p^{c}$ \\
\hline Nil & $100.0 \pm 1.2(71)$ & \\
\hline Antimycin A $(10 \mu \mathrm{mol} / \mathrm{l})$ & $10.7 \pm 3.7(10)$ & $<0.001$ \\
\hline $\mathrm{O}_{2} 70 \%-\mathrm{CO}_{2} 30 \%$ & $118.0 \pm 4.6(15)$ & $<0.005$ \\
\hline Menadione $(1 \mu \mathrm{mol} / \mathrm{l})$ & $97.3 \pm 2.5(9)$ & NS \\
\hline Menadione $(3 \mu \mathrm{mol} / \mathrm{l})$ & $68.8 \pm 5.1(9)$ & $<0.001$ \\
\hline Menadione $(10 \mu \mathrm{mol} / 1)$ & $35.8 \pm 4.0(19)$ & $<0.001$ \\
\hline $\mathrm{NH}_{4}+(0.5 \mathrm{mmol} / 1)$ & $85.9 \pm 4.8(18)$ & $<0.02$ \\
\hline $\mathrm{No} \mathrm{Ca}^{2+}+$ EGTA $(0.5 \mathrm{mmol} / \mathrm{l})$ & $12.5 \pm 1.9(10)$ & $<0.001$ \\
\hline Verapamil $(10 \mu \mathrm{mol} / 1)$ & $8.1 \pm 1.4(9)$ & $<0.001$ \\
\hline Theophylline $(1.4 \mathrm{mmol} / \mathrm{l})$ & $241.7 \pm 3.5(10)$ & $<0.001$ \\
\hline Adrenaline $(5 \mu \mathrm{mol} / 1)$ & $9.0 \pm 2.2(10)$ & $<0.001$ \\
\hline $\mathrm{DP}^{\mathrm{b}}(1 \mu \mathrm{mol} / \mathrm{l})$ & $60.5 \pm 7.1(10)$ & $<0.001$ \\
\hline Cytochalasin B $(20 \mu \mathrm{mol} / 1)$ & $200.6 \pm 10.1(10)$ & $<0.001$ \\
\hline
\end{tabular}

a Mean values \pm SEM are expressed in percentage of the mean control value (first line) found within the same experiment(s). Such a control value averaged $224.5 \pm 4.6 \mu \mathrm{U} /$ islet per $90 \mathrm{~min}$ $(n=71)$. Number of individual determinations in parentheses

b DP: Trifluoromethylphenothiazine derivative of domperidone

c Statistical significance of differences between control and experimental values

tional to the concentration of this amino acid, without any obvious threshold phenomenon (data not shown). Likewise, the facilitation of L-leucine-stimulated insulin output by L-glutamine is dose-related in the physiological range of L-glutamine concentrations [10]. The enhancing action of L-glutamine upon insulin release differs from that of other nutrients in its specificity for a few amino acids. Indeed, Lglutamine fails to stimulate insulin release in the presence of $\mathrm{D}$-glucose, whatever the concentration of 


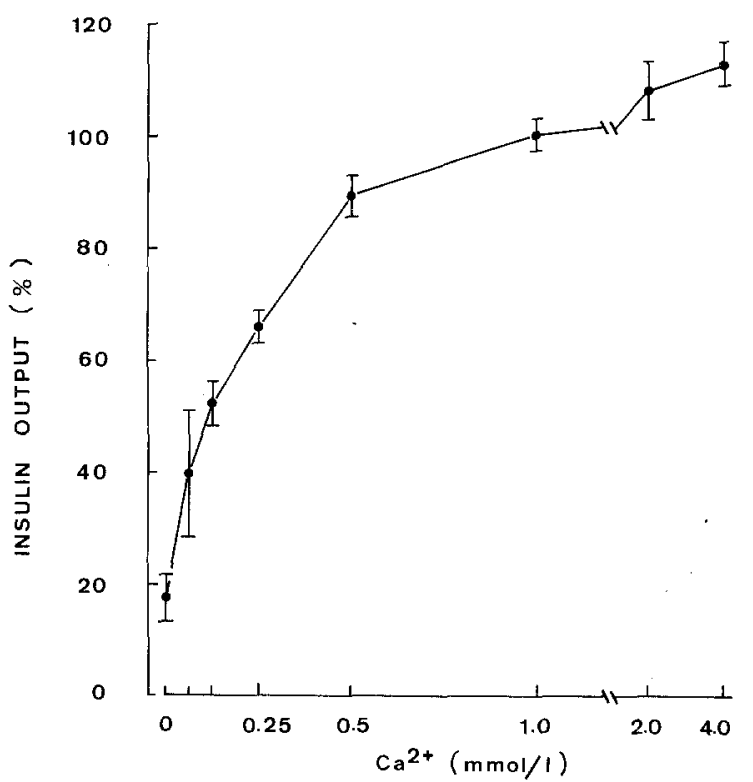

Fig. 3. Effect of increasing concentrations of extracellular $\mathrm{Ca}^{2+}$ upon insulin release evoked by the combination of $\mathrm{L}$-leucine and L-glutamine $(10 \mathrm{mmol} / \mathrm{l}$ each). Mean \pm SEM refer to 9-36 individual measurements and are expressed in percentage of the mean control value found within the same experiment(s) at a $1.0 \mathrm{mmol} / 1$ concentration of $\mathrm{Ca}^{2+}$. Such a reference value averaged $238.6 \pm$ $12.5 \mu \mathrm{U} /$ islet per $90 \mathrm{~min}(n=45)$

the sugar used to stimulate secretion [2]. L-glutamine also fails to affect insulin release in the presence of glycine, L-lysine, L-valine, L-norleucine, L-serine, L-phenylalanine and L-arginine (Table 3). The failure of L-glutamine to affect insulin release in the presence of these amino acids is independent of either their own capacity to stimulate secretion or their ability to augment L-leucine- and D-glucosestimulated insulin output (Table 3). Among the amino acids so far investigated, only L-leucine, its non-metabolizable analogue $b(-) 2$-aminobicyclo$[2,2,1]$ heptane-2-carboxylic acid and, to a lesser extent, L-norvaline and L-isoleucine allowed Lglutamine to cause an increment in insulin release [3]. These are also the only amino acids so far found to act as allosteric activators of glutamate dehydrogenase in islet homogenates, suggesting that this activation plays an essential role in the secretory response to L-glutamine $[3,10]$.

L-glutamine at a close-to-physiological concentration represents a major fuel to cover the basal energy expenditure of islet cells [2]. Its influence
Table 5. Influence of $\mathrm{Ca}^{2+}$ removal and verapamil upon insulin release evoked by L-leucine in the presence of $\mathrm{L}$-glutamine or D-glucose

\begin{tabular}{llll}
\hline $\begin{array}{l}\text { Experimental } \\
\text { variation } \\
(\mathrm{mmol} / \mathrm{l})\end{array}$ & $\begin{array}{l}\text { L-leucine } \\
(10 \mathrm{mmol} / \mathrm{l}) \\
\text { and } \\
\text { L-glutamine } \\
(10 \mathrm{mmol} / \mathrm{l})\end{array}$ & $\begin{array}{l}\text { L-leucine } \\
(10 \mathrm{mmol} / \mathrm{l})\end{array}$ & $\begin{array}{l}\text { and } \\
\mathrm{D} \text {-glucose } \\
(8.3 \mathrm{mmol} / \mathrm{l})\end{array}$ \\
\hline $\begin{array}{l}\mathrm{Nil} \\
\mathrm{Ca}^{2+} \text { absent }\end{array}$ & $207.2 \pm 3.2(18)^{\mathrm{a}}$ & $214.6 \pm 3.3(18)$ & $>0.10$ \\
$\begin{array}{l}\text { Verapamil } \\
(0.01 \mathrm{mmol} / \mathrm{l})\end{array}$ & $10.3 \pm 3.8(9)$ & $23.6 \pm 4.8(9)$ & $<0.05$ \\
\hline
\end{tabular}

a Mean values \pm SEM are expressed as $\mu U /$ islet per 90 min with the number of individual determinations in parentheses

Table 6. Effects of L-glutamine and L-leucine upon biosynthetic activity

\begin{tabular}{|c|c|c|c|}
\hline $\begin{array}{l}\text { Nutrient(s) } \\
(\mathrm{mmol} / \mathrm{l})\end{array}$ & $\begin{array}{l}{\left[{ }^{3} \mathrm{H}\right] \mathrm{IRI}} \\
(\mathrm{fmol} / \text { islet })\end{array}$ & $\begin{array}{l}{\left[{ }^{3} \mathrm{H}\right] \text { TCA- }} \\
\text { precipitable } \\
\text { (fmol/islet) }\end{array}$ & $\begin{array}{l}\text { Ratio }^{c} \\
(\%)\end{array}$ \\
\hline Nil & $1.70 \pm 0.15^{\mathrm{a}}$ & $15.32 \pm 0.38$ & $11.1 \pm 0.9$ \\
\hline L-glutamine $(10)$ & $1.66 \pm 0.15$ & $18.29 \pm 0.90$ & $9.3 \pm 0.7$ \\
\hline L-leucine (10) & $3.31 \pm 0.20$ & $21.38 \pm 1.27$ & $15.6 \pm 0.8$ \\
\hline L-glutamine $(10)$ & & & \\
\hline+ L-leucine $(10)$ & $5.39 \pm 0.29$ & $26.82 \pm 1.08$ & $20.1 \pm 0.8$ \\
\hline
\end{tabular}

a Mean values \pm SEM refer to eight individual determinations b The incorporation of $L-\left[2,4,6-{ }^{3} \mathrm{H}\right]$ phenylalanine $(132 \mathrm{mmol} / \mathrm{l})$ in immunoreactive insulin (IRI) and TCA-precipitable peptides is expressed as fmol/islet per $90 \mathrm{~min}$ (TCA: trichloroacetic acid)

c Ratio of $\left[{ }^{3} \mathrm{H}\right] \mathrm{IRI} /\left[{ }^{3} \mathrm{H}\right] \mathrm{TCA}$-precipitable peptides

upon the fuel-sensor B cell may thus represent an essential feature of the physiological regulation of insulin release by circulating nutrients.

These considerations amply justify a detailed study of the biochemical, biophysical and functional events evoked by L-glutamine in islets exposed to Lleucine. The present study deals solely with the functional events, i.e. biosynthetic and secretory phenomena, evoked by the combination of Lglutamine and L-leucine in the endocrine pancreas. There is very little published information concerning the effect of L-glutamine upon insulin release. However, the capacity of distinct amino acids to affect insulin release in the presence of $\mathrm{D}$-glucose or $\mathrm{L}$ leucine, as reported in this study, is in agreement with data previously collected from studies on rat [11] and rabbit [12] pancreatic tissue, except for the failure of $\mathrm{L}$-arginine to augment L-leucine-induced insulin secretion in the present system.

Our data suggest that the secretory response evoked by the combination of L-leucine and Lglutamine somehow depends on the metabolism of 
the latter amino acid. L-glutamate, which does not easily penetrate islet cells [13], failed to reproduce the effect of L-glutamine (Table 2). However, Lasparagine, which like L-glutamine is readily deamidated in several tissues, shared with L-glutamine the property of enhancing L-leucine-induced insulin release whilst failing to significantly affect $D$-glucosestimulated secretion [2].

It is also conceivable that the catabolism of $\mathrm{L}$ leucine participates in the secretory phenomenon. However, this is rather unlikely because, in the presence of L-glutamine, the non-metabolised analogue of L-leucine, $b(-) 2$-aminobicyclo[2,2,1]heptane-2carboxylic acid, is as potent as L-leucine itself in stimulating insulin release $[3,10]$. Other indications that the metabolic situation of islets exposed to both L-glutamine and L-leucine differs from that of islets incubated with L-leucine alone [9] arise from their vastly different sensitivity to exogenous $\mathrm{NH}_{4}{ }^{+}$or changes in $\mathrm{pCO}_{2}$. At a $0.5 \mathrm{mmol} / 1$ concentration of $\mathrm{NH}_{4}{ }^{+}$, L-leucine-induced insulin release is virtually abolished [14], whereas the release of insulin evoked by the combination of L-leucine and L-glutamine was reduced by no more than $14.1 \pm 4.8 \%$. Likewise, the intracellular acidification resulting from the exposure of islets to a high $\mathrm{pCO}_{2}$ [8] doubled Lleucine-stimulated insulin release [14], but only caused an $18.0 \pm 4.6 \%$ increase in insulin output in the presence of both L-leucine and L-glutamine (Table 4).

These findings are compatible with the fuel hypothesis for insulin release [15], in which the secretory response to nutrients is thought to be associated with an increase in catabolic fluxes. In the present study, the release of insulin provoked by the combination of L-leucine and L-glutamine appeared to be dependent on the integrity of oxidative processes, because it was suppressed by antimycin A (Table 4). Insulin release was also decreased by menadione, which inhibits nutrient-induced insulin release by lowering the islet content of reduced pyridine nucleotides [16, 17]. As is the case with other nutrient secretagogues, the functional response to the combination of L-leucine and L-glutamine included stimulation of biosynthetic activity, with a preferential effect on proinsulin synthesis (Table 6).

A number of other analogues exist between insulin release evoked by L-glutamine and L-leucine and that evoked by other nutrient secretagogues. For instance, both represent calcium-dependent phenomena. In this respect, however, the insulin release evoked by L-glutamine and L-leucine together differed from that evoked by either D-glucose alone [18] or the association of D-glucose and L-leucine (Table 5). The insulin release evoked by
L-glutamine and L-leucine showed greater sensitivity to the absence of extracellular $\mathrm{Ca}^{2+}$ or presence of the organic calcium-antagonist verapamil, and a lower apparent " $\mathrm{Km}$ " for extracellular $\mathrm{Ca}^{2+}$ (i. e. $0.2 \mathrm{mmol} / 1$ in the presence of both L-leucine and Lglutamine, (Fig. 3), as distinct from $0.5 \mathrm{mmol} / 1$ in the sole presence of D-glucose [18]). These findings suggest that different nutrients may exert separate effects upon calcium handling by islet cells. Furthermore, L-glutamine (even in the presence of Lleucine) fails to reproduce the inhibitory effect of $D$ glucose or L-leucine upon ${ }^{45} \mathrm{Ca}$ efflux from perifused islets (unpublished observations).

The process of nutrient-induced insulin release is thought to involve activation of both adenylate cyclase and protein phosphorylation by endogenous calmodulin [19-22]. A comparable phenomenon may be involved in the secretory response to Lglutamine and L-leucine. Indeed, such a response can be potentiated by theophylline, and inhibited by either adrenaline or the trifluoromethylphenothiazine derivate of domperidone, a presumed calmodulin-antagonist (P. Laduron, personal communication). The enhancing action of cytochalasin $\mathrm{B}$ upon insulin release caused by the combination of $\mathrm{L}$ leucine and L-glutamine points to the participation of microfilaments in the secretory process, as previously documented in the case of D-glucose- or L-leucineinduced insulin release [6, 23].

Although these data indicate that insulin release provoked by the combination of $\mathrm{L}$-glutamine and $\mathrm{L}$ leucine shares several features in common with that provoked by D-glucose or other nutrient secretagogues, a striking difference between these two processes should be underlined. Whereas the stimulation of insulin release by most nutrients (e. g. Dglucose, D-glyceraldehyde, D-erythrose, pyruvate, lactate, L-leucine, $\alpha$-ketoisocaproate, $\alpha$-ketocaproate; [24-28] is characterized by a biphasic pattern, the enhancement by L-glutamine of L-leucine-stimulated insulin release was a steadily increasing phenomenon. In the pancreas already exposed to Lleucine, no initial secretory peak occurred in response to L-glutamine administration (Fig. 1). During prolonged exposure to both amino acids, the rate of secretion increased progressively and much more markedly than during prolonged exposure to D-glucose or other nutrient secretagogues. In our opinion, this unusual secretory pattern suggests that much may be learned about the intimate mechanism of insulin release by further investigations of the biochemical and biophysical effects of L-glutamine and L-leucine on pancreatic islets.

In conclusion, the present work indicates that $\mathrm{L}$ glutamine markedly augments L-leucine-stimulated 
insulin release. This phenomenon appears to reflect both the capacity of L-glutamine to act as a fuel and the capacity of L-leucine to activate glutamate dehydrogenase in islet cells. The interaction between these two amino acids is thus compatible with the concept that the nutritional regulation of insulin release is tightly dependent on metabolic events evoked by nutrients in the pancreatic B cell [15].

Acknowledgements. The authors are indebted to J. Schoonheydt, G. Schoonjans, A. Tinant and M. Urbain for technical assistance, and to B. Vincke for secretarial help. This work was supported in part by grants from the Belgian Foundation for Scientific Medical Research.

\section{References}

1. Fajans SS, Floyd JC Jr, Knopf RF, Pek S, Weissman P, Conn JW (1972) Amino acids and insulin release in vivo. Israel $\mathbf{J}$ Med Sci 8: 233-243

2. Malaisse WJ, Sener A, Carpinelli AR, Anjaneyulu K, Lebrun P, Herchuelz A, Christophe J (1980) The stimulus-secretion coupling of glucose-induced insulin release. XIVI. Physiological role of L-glutamine as a fuel for pancreatic islets. Mol Cell Endocrinol 20: 171-189

3. Sener A, Malaisse WJ (1980) Activation allostérique de la déhydrogénase glutamique dans les ilôts de Langerhans: son rôle dans la libération d'insuline induite par les acides aminés. CR Acad Sci Paris 290: 1135-1137

4. Malaisse WJ, Brisson GR, Malaisse-Lagae F (1970) The stimulus-secretion coupling of glucose-induced insulin release. I. Interaction of epinephrine and alkaline earth cations. J Lab Clin Med 76: 895-902

5. Malaisse WJ, Malaisse-Lagae F, Walker MO, Lacy PE (1971) The stimulus-secretion coupling of glucose-induced insulin release. $\mathbf{V}$. The participation of a microtubular-microfilamentous system. Diabetes 20: 257-265

6. Van Obberghen E, Somers G, Devis G, Vaughan GD, Malaisse-Lagae F, Orci L. Malaisse WJ (1973) Dynamics of insulin release and microtubular-microfilamentous system. I. Effect of cytochalasin B. J Clin Invest 52: 1041-1051

7. Leclercq-Meyer F, Marchand J, Leclercq R, Malaisse WJ (1976) Glucagon and insulin release by the in vitro perfused rat pancreas. Influence of the colloid composition of the perfusate. Diab Metab 2: 57-65

8. Carpinelli AR, Sener A, Herchuelz A, Malaisse WJ (1980) The stimulus-secretion coupling of glucose-induced insulin release. XII. Effect of intracellular acidification upon calcium efflux from islet cells. Metabolism 29: 540-545

9. Malaisse WJ, Hutton JC, Carpinelli AR, Herchuelz A, Sener A (1980) The stimulus-secretion coupling of amino acidinduced insulin release. I. Metabolism and cationic effects of leucine. Diabetes 29: 431-437

10. Sener A, Malaisse WJ (1980) L-leucine and a non-metabolizable analogue activate pancreatic islet glutamate dehydrogenase. Nature 288: 187-189

11. Malaisse WJ, Malaisse-Lagae F (1968) Stimulation of insulin secretion by noncarbohydrate metabolites. J Lab Clin Med 72: $438-448$

12. Milner RDG (1970) The stimulation of insulin release by essential amino acids from rabbit pancreas in vitro. $J$ Endocr 47: 347-356

13. Sehlin J (1972) Uptake and oxidation of glutamic acid in mammalian pancreatic islets. Hormones 3: $156-166$
14. Sener A, Malaisse WJ (1980) The stimulus-secretion coupling of amino acid-induced insulin release. II. Sensitivity to $\mathrm{K}^{+}$, $\mathrm{NH}_{4}{ }^{+}$and $\mathrm{H}^{+}$of leucine-stimulated islets. Diab Metab 6: 97-101

15. Malaisse WJ, Sener A, Herchuelz A, Hutton JC (1970) Insulin release: the fuel hypothesis. Metabolism 28: 373-386

16. Malaisse WJ, Sener A, Boschero AC, Kawazu S, Devis G, Somers $G$ (1978) The stimulus-secretion coupling of glucoseinduced insulin release. XXX. Cationic and secretory effects of menadione in the endocrine pancreas. Eur J Biochem 87: 111-120

17. Malaisse WJ, Hutton JC, Kawazu S, Sener A (1978) The stimulus-secretion coupling of glucose-induced insulin release. XXXI. Metabolic effect of menadione in isolated islets. Eur J Biochem 87: 121-130

18. Malaisse WJ, Hutton JC, Sener A, Levy J, Herchuelz A, Devis G, Somers G (1978) Calcium antagonists and islet function. VII. Effect of calcium deprivation. J Membrane Biol 38: 193-208

19. Valverde I, Vandermeers A, Anjaneyulu R, Malaisse WJ (1979) Calmodulin activation of adenylate cyclase in pancreatic islets. Science 206: 225-227

20. Sharp GWG, Wiedenkeller DE, Kaelin D, Siegel EG, Wollheim CB (1980) Stimulation of adenylate cyclase by $\mathrm{Ca}^{2+}$ and calmodulin in rat islets of Langerhans. Diabetes 29: 74-77

21. Gagliardino JJ, Harrison DE, Christie MR, Gagliardino EE, Ashcroft SJH (1980) Evidence of the participation of calmodulin in stimulus-secretion coupling in the pancreatic $\beta$-cell. Biochem J 192: 919-927

22. Schubart UK, Erlichman J, Fleischer N (1980) The role of calmodulin in the regulation of protein phosphorylation and insulin release in hamster insulinoma cells. J Biol Chem 255: $4120-4124$

23. Levy J, Herchuelz A, Sener A, Malaisse-Lagae A, Malaisse WJ (1976) Cytochalasin B-induced inpairment of glucose metabolism in islets of Langerhans. Endocrinology 98: 429-437

24. Malaisse WJ, Herchuelz A, Levy J, Sener A, Pipeleers DG, Devis G, Somers G, Van Obberghen E (1976) The stimulussecretion coupling of glucose-induced insulin release. XIX. The insulinotropic effect of glyceraldehyde. Molec Cell Endocrinology 4: 1-12

25. Sener A, Devis G, Somers G, Malaisse WJ (1977) The insulinotropic action of D-erythrose. Diabetologia 13: 125-130

26. Sener A, Kawazu S, Hutton JC, Boschero AC, Devis G, Somers G, Herchuelz A, Malaisse WJ (1978) The stimulussecretion coupling of glucose-induced insulin release. XXXIII. Effect of exogenous pyruvate on islet function. Biochem J 176: 217-232

27. Malaisse WJ, Kawazu S, Herchuelz A, Hutton JC, Somers G, Devis G, Sener A (1979) The stimulus-secretion coupling of glucose-induced insulin release. XXXIV. Effect of lactate upon islet function. Arch Biochem Biophys 194: 49-62

28. Hutton JC, Sener A, Herchuelz A, Atwater I, Kawazu S, Boschero AC, Somers G, Devis G, Malaisse WJ (1980) Similarities in the stimulus-secretion coupling mechanisms of glucose- and 2-keto acid-induced insulin release. Endocrinology 106: 203-219

Received: 16 December 1980

and in revised form: 13 April 1981

Dr. W. J. Malaisse

Laboratory of Experimental Medicine

Université Libre de Bruxelles

115, Boulevard de Waterloo

B-1000 Brussels, Belgium 